\title{
Calvinus: Auctoritas Dei (Calvin: The authority of God)
}

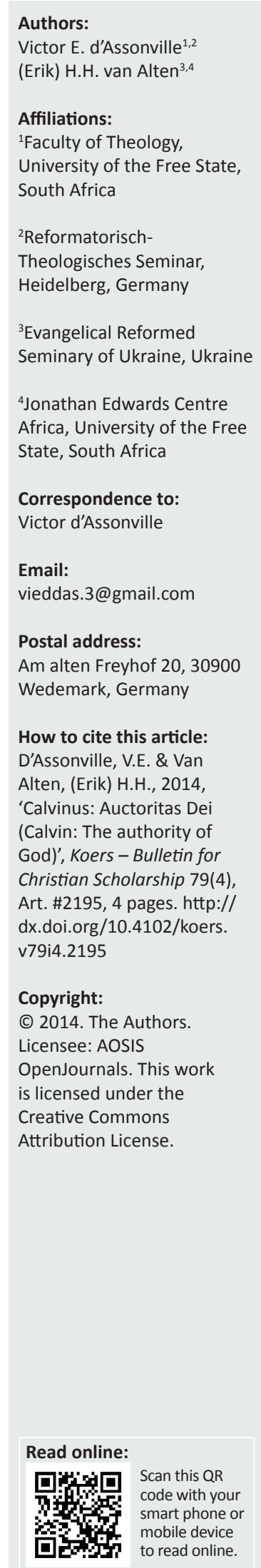

\section{Inleiding}

... geen ouer, of heerser of owerste van watter aard ook al het enige gesag, heerskappy of eer as dit nie uit God se raadsplan spruit nie, omdat dit Hom behaag om die wêreld so te bestuur. (Aanhaling uit antwoord 196 van die Geneefse Kategismus van 1542/1545) ${ }^{1}$

Die negende amptelike Suid-Afrikaanse Kongres vir Calvynnavorsing, wat vanaf 15-17 Augustus 2012 in Pretoria aangebied is, het in 'n sekere opsig 'n unieke weg ingeslaan. Vir die eerste keer sedert die ontstaan van die Suid-Afrikaanse Calvynnavorsingskongres in 1980 is hierdie kongres nie by een van die tradisionele universiteite aangebied nie, maar by private lokale, naamlik die fasiliteite van Solidariteit in Groenkloof, Pretoria, wat goedgunstiglik deur hierdie organisasie beskikbaar gestel is. Verder is dit aangebied in samewerking met Aros (Aksie Reformatoriese Opleiding en Studies), 'n tersiêre instelling wat hom sedert 2004 beywer vir die opleiding van Christelike onderwysers. Die organiseerders se opregte dank gaan uit na hierdie instellings vir hulle insette en bydraes. Maar ten spyte van nuwe weë was daar ook die vertroude weg van deeglike navorsing oor Calvyn vanuit die primêre bronne.

Oudergewoonte is die Suid-Afrikaanse Kongres vir Calvynnavorsing vereer met internasionale sprekers. Prof. dr. Peter Opitz, direkteur van die Instituut vir Switserse Reformasiegeskiedenis in Zürich, het was verantwoordelik vir 'n hoofvoordrag sowel as 'n seminaar tydens die kongres. Ook prof. dr. Erik de Boer, verbonde aan die Teologiese Universiteit in Kampen (Nederland) en 'n gereelde deelnemer aan die Suid-Afrikaanse Calvynnavorsingskongresse, het 'n hoofvoordrag en seminaar aangebied. Vir talle kongresdeelnemers was die bydraes van hierdie internasionale sprekers voorbeelde van geïntegreerde en deeglike navorsing.

Hoewel die negende Suid-Afrikaanse Kongres vir Calvynnavorsing nie 'n spesifieke tema gehad het nie, het die redakteurs besluit om aan hierdie bundel die titel 'Calvinus: Auctoritas Dei' ('Calvyn: Die gesag van God')

1.CO 6, 70; OS II, 106; Afrikaanse vertaling deur prof. H.W. Simpson (Calvyn 1981:35).

\section{Introduction}

... for there is no authority whether of parents, or princes, or rulers of any description, no power, no honor, but by the decree of God, because it so pleases him to order the world. (Quotation from the Catechism of Geneva of $1542 / 1545)^{1}$

The ninth official South African Congress on Calvin Research, which was held from the 15-17th of August 2012 in Pretoria, in some sense explored new avenues. For the first time since the initiation of the South African Congresses on Calvin Research in 1980, this congress was not held at one of the traditional universities, but at a private venue, namely that of Solidarity in Groenkloof, Pretoria, which was kindly made available by this organisation. Furthermore, it was presented in cooperation with Aros (Aksie Reformatoriese Opleiding en Studies), a tertiary institution that has been striving for the education of Christian teachers since 2004. The organisers want to thank these institutions for their input and contributions. But despite these new avenues there was still the familiar way of solid Calvin research from the primary sources.

As has become customary, the South African Congress on Calvin Research was honoured to have renowned international scholars in attendance. Prof. dr. Peter Opitz, director of the Institute for Swiss Reformation History in Zurich, delivered a plenary paper and led a seminar as well during the congress. Prof. dr. Erik de Boer from the Theological University in Kampen (the Netherlands) and a regular visitor to the South African Congresses on Calvin Research, also delivered a plenary paper and presented a seminar. For many participants of this congress the contributions of these international scholars were examples of integrated and thorough research.

Although the ninth South African Congress on Calvin Research did not have a specific theme, the editors decided to give this volume the title 'Calvinus: Auctoritas Dei' ('Calvin: The authority of God'). This is due to an unexpected theme emerging from several of the articles, namely the theme of the 1.CO 6, 70; OS II, 106; for an English translation, cf. Reid (1956). 
te gee. Dit is te danke aan die feit dat 'n tema in verskeie van die artikels na vore gekom het, naamlik die tema van gesag. In die eerste deel van die bundel is hierdie tema meer eksplisiet, terwyl dit in 'n meer afgeleide sin in die tweede deel na vore kom.

Die bundel open met 'n artikel van Dolf Britz, 'Calvin's instruction on the fifth commandment.' Vanweë omstandighede kon hierdie voordrag nie tydens die kongres gelewer word nie. Tog bied dit 'n goeie basis vir Calvyn se visie op gesag. Britz ontleed verskeie geskrifte en toon die kontinuïteit in Calvyn se visie aan, veral met betrekking tot drie spesifieke hoofmotiewe: die struktuur van gehoorsaamheid, die belofte verbonde aan die vyfde gebod, en die oordeel in die geval van oortreding van hierdie gebod. Ook die uitbreiding van ouerlike gesag na die gesag van onderwysers en regeerders is van belang. Hierby sluit Gerard Meijer se artikel oor die Geneefse Skoolorde goed aan. Deur hierdie fundamentele dokument te ondersoek, toon Meijer basiese lyne vir 'n Gereformeerde Skoolorde aan. Uiteraard speel dissipline - die gesag van die onderwysers en die gehoorsaamheid van die leerlinge - 'n belangrike rol hierin, maar ook ander lyne soos leerplan, die rol van ouers, en die struktuur van die skool kom na vore. Wyle Johann Potgieter se artikel, 'Claude Le Jeune and Theodore de Bèze: A first encounter in the Dix Pseaumes ... en forme de Motets of 1564 ', neem 'n besondere posisie in hierdie bundel in. Die outeur het hierdie artikel in 2005 volgens 'n gebruiklike Europese bibliografiese verwysingsmetode vir wetenskaplike publikasies voltooi. Die inhoud is van sodanige gehalte dat die redakteurs gemeen het dat dit belangrik is om dit aan ' $n$ wyer publiek ter beskikking te stel. Die inhoud is ongewysig gelaat, maar die redakteurs het, met die hulp van Eric Kayayan, tegniese en taalkundige aspekte versorg. In hierdie artikel ondersoek Potgieter die versameling Franse psalms, Dix pseaumes, waarvan Claude Le Jeune die komponis was en waarvoor Theodore de Bèze die tekste berym het. Die outeur maak duidelik dat hierdie werk gelees behoort te word teen die agtergrond van die vervolging van die Protestante in Frankryk deur, onder andere, Charles de Guise. Hierdie agtergrond het die vraag na die reg van opstand teen die regering na vore gebring, en Potgieter argumenteer dat dít die keuse en rangskikking van die psalms in Dix pseaumes bepaal het. Erik de Boer sluit die eerste helfte van die bundel af met ' $n$ artikel oor die oordrag van leierskap in die lig van Calvyn se kommentaar op die boek Josua. De Boer toon aan dat Calvyn besondere aandag geskenk het aan die dood van Ou Testamentiese leiers soos Moses en Josua, en dat hy, by die uitleg van die boek Josua, bewus was van sy eie naderende dood en die belang van die oordrag van leierskap.

Terwyl die artikels in die eerste helfte van die bundel duidelik met verskillende sfere van gesag (gesin, skool, owerheid, kerklike leiding) saamhang, kan dit in 'n afgeleide sin ook van die tweede helfte gesê word. Grondliggend aan Calvyn se verstaan van gesag is naamlik sy oortuiging van die gesag van God en sy Woord. Hierdie oortuiging, hoewel te algemeen om op sigself die titel van die bundel te regverdig, authority of God. In the first part of this volume this theme is more explicitly present, whilst it emerges in a more implicit way in the second part.

The volume starts with an article by Dolf Britz, 'Calvin's instruction on the fifth commandment'. Owing to circumstances, this article could not be delivered during the congress. Nonetheless, it still serves as a good basis for Calvin's view on authority. Britz researches several writings and indicates the continuity in Calvin's view, in particular with regard to three main motives: the structure of obedience, the promise attached to the fifth commandment, and the judgement in the case of transgression of this commandment. The extension of parental authority to the authority of teachers and governments is also of importance. Gerard Meijer's article on the Genevan School Order links well to this theme. By researching this fundamental document, Meijer indicates basic principles for a reformed school order. Of course discipline - the authority of teachers and the obedience of learners - plays an important role in the school order, but there are also other fundamental aspects such as the curriculum, the role of parents and the structure of the school. The late prof. Johann Potgieter's article, 'Claude Le Jeune and Theodore de Bèze: A first encounter in the Dix Pseaumes ... en forme de Motets of 1564', assumes a special position in this volume. The author completed this article in 2005 according to a customary European bibliographical reference method for scientific publications. The contribution is of such a standard that the editors were convinced of the importance of making it available to a wider public. The contents were left unchanged, but with the help of Eric Kayayan the editors took care of the technical and linguistic aspects. In this article Potgieter researches the collection of French psalms, Dix pseaumes, of which Claude Le Jeune was the composer. Theodore de Bèze versified the texts of these psalms. The author clearly shows that this work should be read against the background of the persecution of the Protestants in France by, amongst other figures, Charles de Guise. This background raised the question of the right to civil disobedience, and Potgieter argues that it influenced the choice and the arrangement of the psalms in Dix pseaumes.

Erik de Boer closes the first half of this volume with an article about the transference of leadership against the background of Calvin's commentary on the book of Joshua. De Boer shows that Calvin devoted a lot of attention to the death of Old Testament leaders such as Moses and Joshua, and that he, in explicating the book of Joshua, was aware of his own pending death and the importance of the transference of leadership.

Whereas the articles of the first half of the volume are clearly related to different spheres of authority (family, school, government, ecclesial leadership), this can also be said in a derivative sense of the articles in the second half. After all, underlying Calvin's understanding of authority is his conviction of the authority of God and his Word. This conviction, although too general to justify the title of this volume by itself, still offers an umbrella under which the 
bied nogtans 'n sambreel waaronder die artikels in die tweede helfte gegroepeer kan word. Al hierdie artikels gaan naamlik oor God se gesag oor die lewe en die gesag van sy Woord in die vasstelling van die verkondiging en die leer.

Victor d'Assonville se artikel oor Calvyn se sendingbeskouing lei hierdie deel in. Die hardnekkige bewering dat Calvyn geensins of weinig in sending geïnteresseerd was, word oortuigend weerlê. Volgens Calvyn het alle gelowiges 'n verantwoordelikheid in die uitdra van die evangelie. Die adressate van hierdie 'sendingwerk' is alle volke, alle mense, die hele wêreld. Hy bind die sendingtaak ekklesiologies in: Vir hom is die kerk (plaaslike gemeente) slegs dan kerk, wanneer dit missiologies georiënteerd is. Morné Diedericks se artikel handel oor Calvyn se visie op die voorsienigheid van God. Hy fokus in besonder op Calvyn se debat met Castellio en pas dit toe op Adrio König se kritiek op Calvyn se voorsienigheidsleer. In sy verstaan van God se voorsienigheid verwerp Calvyn nooit God se soewereiniteit nie, maar gee hy ook nie vir God die skuld vir die kwaad nie. God gebruik juis teenspoed en verdrukking om sy kinders nader aan Hom te lei.

In sy artikel vergelyk Frikkie Mulder Calvyn se visie op die Roomse mis met vraag en antwoord 80 van die Heidelbergse Kategismus. Hy is van mening dat Calvyn en die Heidelberger in wese dieselfde verwerping van die Roomse mis, soos geformuleer in die konsilie van Trente, bevat. Die gesag van die Woord word geplaas teenoor die gesag van formules soos uitgespreek deur die priesters.

Erik van Alten se artikel, 'Calvyn se visie op die boek Handelinge van die Apostels', is 'n bespreking van Calvyn se gebruik van inleidende dokumente, soos die argumentum en opdragbriewe, om die reformator se visie op die boek Handelinge uiteen te sit. Die boek Handelinge het, volgens Calvyn, veral 'n Christologiese en ekklesiologiese inslag - Christologies, aangesien dit die effek van Christus se aardse werk beskryf; ekklesiologies, omdat dit die begin en voortgang van die kerk vir ons skilder.

Die bundel word afgesluit met 'n artikel van Adriaan Neele, getiteld 'Post-reformation Reformed exegesis: Continuity or discontinuity of John Calvin?'. Die titel dui aan dat ons intussen verby die tyd van Calvyn beweeg het en die postreformatoriese tydperk betree het - vandaar die plasing aan die einde van die bundel. In hierdie artikel vergelyk Neele Calvyn se uitleg van die Psalms met dié van Petrus van Mastricht. Sodoende gee hy 'n indruk van die (eksegetiese) gesag wat Calvyn gehad het in die tyd ná die Reformasie. Ofskoon Van Mastricht vir Calvyn aanbeveel as een van die beste eksegete van die Skrif, verwys hy in sy werke selde na Calvyn.

'n Hartlike woord van dank aan Helena Hoogstad, hoofredakteur van Koers, asook haar hele span (in die besonder Duncan Hooker van AOSIS OpenJournals ${ }^{\circledR}$ ) vir hulle onvermoeide en konsensieuse aandeel in die redaksionele werk aan hierdie band. articles of the second half can be grouped. All these articles are about God's authority over life and the authority of his Word in determining teaching and doctrine.

Victor d'Assonville's article on Calvin's view on mission serves as introduction. The stubborn impression that Calvin had little or no interest in mission is convincingly challenged. According to Calvin, every believer has a role to fulfil in evangelism. The 'mission field' is composed of every nation, all peoples, the entire world. Calvin interprets the task of mission ecclesiologically: for him the church (as local congregation) is only church when it has a missiological orientation.

Morné Diedericks' article deals with Calvin's view on the providence of God. He focuses in particular on Calvin's debate with Castellio and applies this to Adrio König's critique of Calvin's doctrine of providence. In his understanding of God's providence Calvin never rejects God's sovereignty, but he also does not blame God for evil. God uses adversity and tribulation to draw his children closer to Him.

In his article, Frikkie Mulder compares Calvin's view on the Roman mass with question and answer 80 of the Heidelberg Catechism. He is of the opinion that Calvin and the Catechism in essence have the same rejection of the Roman mass, as formulated at the Council of Trent. The authority of the Word is placed over and against the authority of certain formulas as pronounced by the priests.

Erik van Alten's article, 'Calvin's view on the book of the Acts of the Apostles', is a discussion of Calvin's use of introductory documents, such as the argumentum and the dedicatory letters, to explain the reformer's view on the book of Acts. The book of Acts has, according to Calvin, both a Christological and an ecclesiological impact - Christological, because it describes the effect of Christ's earthly work; ecclesiological, because it paints a picture of the beginning and progress of the church.

The volume closes with an article by Adriaan Neele entitled, 'Post-reformation Reformed exegesis: Continuity or discontinuity of John Calvin?'. The title indicates that we have moved past the time of Calvin and have entered the time of the post-reformation - hence its placement at the end of the volume. In his article, Neele compares Calvin's exegesis of the Psalms with that of Petrus van Mastricht. In this way he gives an impression of the exegetical authority that Calvin had in the theology after the Reformation. Although Van Mastricht recommends Calvin as one of the best expositors of Scripture, he seldom refers to Calvin in his works.

A sincere word of thanks is appropriate to Helena Hoogstad, editor-in-chief of Koers, as well as her whole team (especially Duncan Hooker, AOSIS OpenJournals ${ }^{\circledR}$ ) for their tireless zeal and conscientious work. 
Die redakteurs se hoop is dat hierdie bundel verdere Calvynnavorsing in Suid-Afrika sal stimuleer, en navorsers bewus sal maak van die nuutste navorsing op hierdie terrein.

\section{Literatuurverwysings}

Calvin, J., 1981, Calvyn se Kategismus, vert. H.W. Simpson, Potchefstroomse Teologiese Publikasies, Potchefstroom.
The editors' hope is that this volume will stimulate ongoing Calvin research in South Africa and make scholars aware of the most recent research in this area.

\section{References}

Reid, J.S.K., 1956, Calvin: Theological treatises [Library of Christian classics], The Westminster Press, Philadelphia. 